\title{
Nigeria: A Rogue State in the Wake of Umar Farouk Abdulmutallab's Terror Adventure?
}

\author{
Lere Amusan, Ph.D \\ Department of Politics and International Relations, North West University, South Africa \\ Email: Lere.amusan@nwu.ac.za \\ Adebowale Idowu Adeyeye, PhD candidate
}

Department of Politics and International Relations, North West University, South Africa

Doi:10.5901/mjss.2014.v5n23p1866

\begin{abstract}
The western world perception of the Third World States (TWS) in general and Africa in particular continues to generate academic curiosity. When it is suitable for the North, name tagging will be accorded to these states. The December 2009 attempted bombing of the Detroit bound Delta airline by Umar Farouk Abdulmutallab (UFA), a Nigerian, relegated the erstwhile darling of the West to a 'concern state', a diplomatic way of addressing it as a rogue/terrorist enclave. As long as America continues to dictate the tune, the objectivity of placing each state on the level of its political and economic status will remain a mirage. Issues that always garner nuances are among others, the concept of terrorism, rogue/pariah and militant state. Seeing Nigeria as a terrorist state to be watched could be said to be a continuation of double standard of the Eurocentric dominated international system. While some European states are noted for their incessant bombings, but remain trusted allied of Washington, the UFA misadventure was politicised in spite of Nigeria's not only being pro-American stance, but also being a fervid supporter of the European Union's orientation and policies. To understand phenomenon of terrorism, there is a need to have a global look into it as against state-centric approach. To curtail terrorism in the country, economic and educational systems that are domestically planned, executed and evaluated are needed.
\end{abstract}

Keywords: Nigeria-US Relations; Abdulmutallab; Terrorism; Climate Change; Sustainable Development

\section{Introduction}

Like any other concepts in social sciences, pariah, rogue and terrorism are difficult to define. "The difficulty in the definition of those terms lies in semantics and context driven by subjective interpretations often conferred on them reflecting the interests and values of the participant, victim, targets, the onlooker, analysts or sections of the international system" (Guy, 2006: 51). Pariah or rogue state is also known to be outlaw states actors, which, by virtue of their political systems, ideological postures, leaderships or general behaviour, suffer diplomatic isolation and widespread global moral opprobrium (Evans \& Newham 1998:417). ${ }^{1}$ On the other hand, terrorism can be variously defined according to the orientation and background of the reviewer. According to Hübschle (2006:2) "the definition and meaning of terrorism lie in the eye of the beholder." As long as there is no universal acceptable definition of this concept, it is apropos to look into the ingredients of terrorism and see if one can place it in a proper perspective, free of ideological inclination and environmental factor. Some of these variables are:

- There should be some degree of fear-inducement, both horizontally and vertically.

- It is ruthless.

- There is disregard for established humanitarian values and an unquenchable thirst for publicity;

- Other features are: hijacking, hostage taking, bombings, indiscriminate shootings, assassinations and mass murders.

- It may be state or non-state inspired in form of political or factional terrorism.

This study shall examine some common variables that are associated with the 25th December 2009 (hence 12/25)

${ }^{1}$ A rogue state is defined by Flint \& Taylor (2007: 124) "as one that did not follow the norms of international security...the label was attached to those countries that were challenging US power." Evans \& Newnham (1998: 417) see pariah and rogue concepts as the same; they defined them as "outlaw states, international actors, which by virtue of their political system, ideological postures, leaderships or general behaviour suffer from diplomatic isolation and widespread global moral opprobrium." 
terrorist attack on the Delta airline heading for Detroit from Amsterdam as carried out by a twenty-three year old Nigerian, was billed to cause mayhem at the global level. Different school of thoughts have emanated on this development. It was America's position that the Nigerian born "underwear bomber" had a strong link with the Islamic fundamentalists from the Northern part of Nigeria, Al Queda in the Arabian Peninsula and Anwar al-Awlaki. The veracity of these claims is part of our departure. Also of crucial note is the need to test some assertions of the causes of terrorist acts such as poverty, martyrdom, nationalism, ethno-national factor and dividends of climate change (Abdalla 2010:11). Other perspectives to situate this study with are ethnic crisis, religious conflict (clash of civilization/a clash about civilization or what Kepel (2004) called The War for Muslims Mind) and frustration-aggression thesis and what Dominique Moïsi (2007, 2009) described as America's fear and Arab's humiliation factors. ${ }^{2}$ These shall be interrogated to find some links with UFA's mis/adventure. The belief by some scholars that those involved in terrorism are of middle class, ${ }^{3}$ professionals and highly educated individuals is also an issue for academic interrogations. Situating UFA issue with these paradigms will more lights on the reasons why he embarked on the mission despite his promising family background, quality education and international exposure.

The idea of 'one-size-fit-all' by the US on its war-on-terror will receive some academic debate. It will be pointed out that lack of a coherent description of the concept of terrorism and ability to confer personal meanings is a subject of social problem. Equally important is a discussion on the umbilical cord between the Hausa/Fulani of the core North in Nigeria and some questionable states that are known for their terrorist activities such as Afghanistan, Algeria, Iraq, Iran, Egypt, Palestine, Lebanon, Libya, Pakistan, Saudi Arabia, Somalia, Yemen, Syria and Sudan.

This paper argues that the issue of labelling Nigeria as a terrorist state was politically motivated because of the US economic, political and social interests in the state, mostly in the oil and gas sectors. Among the recommendations of this paper is to call for a functional social contract between state and individuals. Secularism and poverty eradication initiatives should be the target of the Nigerian state as against the dictate of the West through globalisation approach of which solution to terrorism is "antithesis of globalisation" (Agbu, 2004: 326).

\section{Terrorism as a Concept in Security Studies}

As mentioned above, it is difficult to give a concise definition of the concept of terrorism. The use depends on the intention of the user and for what purpose. Various definitions ranging from the small power (Third World), medium power, to the Great power (First World) perspectives shall be looked into. In his definition of terrorism, Kofi Annan (2005), the former UN scribe sees it as an intention to cause death or serious bodily harm to civilians or non-combatants, with the purpose of intimidating a population or compelling a government or international organisation to do something or not to do something. As Annan and other students of international politics of his school tried to give a broad based definition to the concept, the US and its allied, mostly the European Union (EU), expectedly, gave a narrow view for the purpose of justifying their counter-terrorism attack on the perceived terrorists and their ancillary interests. They viewed it as a weapon by non-state actors to achieve political end. The West, therefore, could not see the need for liberation movements, the need to seek some degree of redress from a national government when there is evidence of neglect caused by sectionalism, ethno-nationalism and politics of prebendalism. The environmental crisis, for instance, that reduced the Touaregs in Mali and Niger to foreigners in their own states, coupled with the discovery of gold and uranium caused displacement of the tribe to the benefit of the sedentary Songhay. Attempt by the Touaregs to seek for equity, justice and equality was labelled a terror act. Attempts to seek redress through positive protests were termed as terrorism act, going by the great power's interpretation of the concept (Abdalla, 2010:10).

Therefore, "the word terrorism has been so overused in recent years that it's now commonly used simply to

\footnotetext{
2 Terrorism as an agent of religious intolerance is being subjected to academic curiosity recently. As much as some scholars, (Samuel $P$. Huntington (1996) and Moïsi Dominique (2007, 2009), mostly from the western world, are of the view that the leitmotif of changing the existing status quo by the Islamic world is the harbinger of terrorist attack on the civilized states. Also germane is the paper writing by Tony Blair (2007) where he observed that the issue is between the Muslims and the West and tagged it as a clash about civilization against Huntington's Clash of Civilization. In the same vein, Gilles Kepel's (2004) The War for Muslim Minds: Islam and the West contributes to the anti-West of the Muslim world perspective.

${ }^{3}$ The middle-class Brigate Rosse (Red Brigades) spearheaded Italian left-wing terrorism who regarded Italy as a bourgeois dictatorship and the language of armed resistance as the only language understood by the ruling class. Because of the political exposure and the level of their education, they were able to attract support from the former Soviet Union and many eastern European states. it is equally the view of some students of terrorism such as Micheal Burleigh (2009:443) when he opined that "Al- Qaeda puts a premium on welleducated middle-class professional operatives because they live otherwise model lives, and can move around with relative impunity under the cover of doing good..."
} 
stigmatize any individual or group one doesn't like, for almost any kind of behaviour involving force" (Blum, 2003).

Thomas Friedman (New York Times 1998 August 22: 15) defines terrorists as a group of people who "have no specific ideological program or demands. Rather, they are driven by a generalized hatred of the US, Israel and other supposed enemies of Islam". From Friedman's definition one can fathom the reason why President George W. Bush concludes "that terrorists are people who hate America and all that it stands for: its democracy, its freedom, its wealth, its secular government (Blum, 2006:29). This view is idée reçue because the basis of the crisis between the Muslim world and the US has more to do with the latter's foreign policy towards Israel and the Middle East. The policy has not been promoting liberal democracy and all that it stands for (Jewish Conspiracy, n.d.: 77-81). In his own view, William Blum sees terrorism as "the deliberate use of violence against civilians and property to intimidate or coerce a government or the population in furtherance of a political objective (Blum, 2006:32). Also, Evan and Newham (1998:530) define it as "the use of violence on a systematic basis to achieve political objectives". From his own perspective, Tom Imobighe (2009:20) defines it, which is going to be the basis of this discussion, as: indiscriminate use of different levels of violence, ranging from hostage taking and assassinations to the use of explosives and bombs for the management of a hostile relationship in which the target is not limited to the main combatants, but inclusive of all those with ancillary relationships with the target enemy and in which the overall aim is to impose one's will on the latter

The followings are the attributes of terrorist activities according to Imobighe (2009:15):

- Terrorism occurs in an environment of conflict and discord, and hence it is a product of conflict escalation.

- Terrorism is a violent mode of response to a conflictual relationship.

- The target of terrorism is not limited to the parties directly involved in the conflictual relationship, but includes everybody directly or remotely associated with the principal actors or combats.

- The objectives of terrorism are varied and not always political.

From the above four issues raised by Imobighe, it could be observed that the objective of the terrorist is not only related to political ambition, but also to religion, ethno-national, environmental degradation (the effect of climate change), and unequal economic exchange as patterned by the Eurocentric international economic relations system.

The thesis of political ambition mistake as the sole cause of terrorism was equally made by the United Nations General Assembly (UNGA) as it is contained in its Resolution 54/110 of December 9, 1999. The resolution defines terrorisms as "criminal acts intended or calculated to provoke a state of terror in general public, a group of persons or persons for political purposes." The call for the changes in the existing status quo as championed by the international jihadists could be said to have some political colourations because the dominant ambition of the US in the international system continues to be a snag for some emerging states. The support rendered to some terrorists in Mali and Niger for economic reason in form of mineral exploration rights is a case in point that confirms some economic imperatives in terrorist activities (Abdalla 2010:11).

As a result of the unspoken crisis between the East and the West, a cold war of another dimension brought about a conflict that had no border because of the involvement of non-state actors. This is reminiscent of the Cold War unconventional (guerrilla) war admixture of regular tactics. This time, the Islamic fundamentalists and the liberal proAmerican states are at war against each other. The only available option in the view of the weak states to further their interest against the US led west is the adoption of terrorist behaviour. As long as the weak side could not go into a conventional war against their target, adoption of undistinguished attack against the civilian, mostly women, the old and their children, including their ancillary interests, is inevitable. However, the strong side has, at least, two alternatives in prosecuting its war against perceived enemies. As discussed below, the Great Powers equally resorted to terrorism through Special Operations and Drones that led to the mass killing of civilians in Afghanistan, Iraq, Libya, Mali, and Syria. Having defined what terrorism is all about in line with the objective of this debate, this study will now examine the conditions that brought about the attack and how the same affected the image of Nigeria at the global level.

\section{Nigeria's Image in the Wake of UFA Adventure/Misadventure}

Various variables determine a state's foreign policy. As earlier mentioned, there is a need to look into Nigeria's image in the wake of the attempted bombing of a US bound airline from Amsterdam (Holland) to Detroit (USA). The choice of the festive season as a target of inflicting another 'punishment' on the US could be said to be political with some religious implications for the western Christian world. The timing was a critical period as Nigeria's foreign policy nose-dived, at best in a state of coma because the country then lacked a functional head of government to effectively relate with the international system. The previous cases of domestic terrorism in Nigeria were issues of international concern because of the loss of civilian lives in the process: The 1980s Maitatsine riot, ethnic crises in the Southern part of Kaduna state 
between the settlers and indigenes in Zango-Kataf, the Shagamu mayhem, the Idi-Araba skirmishes between the Hausa and the Yoruba ethnic groups, the Boko Haram religious crises in the north-eastern part of the country and the sporadic Jos crises could be said to have reduced the country to a terror enclave. Boko Haram issue is being aggravated to a global concern because of the March 2014 kidnap of 278 school girls in Borno state. This hopefully will bring the attention of the great powers to holistically resolved the causes of insurgency in Africa in general.

Nigeria's history as a hot-bed of ethno-national and religious crises is a known development to the western world, but because of the direct effect the 12/25 case had on Americans made the Washington government declare Nigeria as a state of concern. The introduction of a political sharia law in the northern part of Nigeria in 2003, despite the Nigerian 1999 Constitution, Section 10 declaration that "the Government of the Federation or of a State shall not adopt any religion as State Religion", was not conceived as part of international terrorism because it did not directly affect America's internal political arrangement. Also, the mayhem inflicted on the people of Yobe and Borno States in the north-eastern part of the country by Boko Haram, the 2009 procession by the Sheikh El-Zakzakky's pro-Shiite movement, Jama'atu Nasil Islam (JNI) that claimed responsibility for the 17 January 2010 Jos crisis in a bid to Islamize northern Nigeria were downplayed by the American government since it did not affect the oil production in the Niger Delta ( an economic interest of the West). ${ }^{4}$

\section{Abdulmuttalab and his Western Connection}

The claim that UFA's father reported his son to the American security agents before the attempted incident call for some academic interrogation. One could come up with some questions on why the father contacted American security agents and not Nigeria's? Did he do this because he realised that Nigeria could not handle such a problem having being relegated to a failed state ${ }^{5}$ Put differently, was it that the son's case could only be handled by a perceived world government leader since Umar is a product of the West? Also worth looking into is the identity of the culprit. UFA came from wealthy family that was able to send him to elite schools in the United Kingdom, Essence International School and Zamani College, Kaduna,--elitist schools for Hausa/Fulani ethnic group in the North. Perhaps, this confirmed the above listed indices of a terrorist, extraction from the middle class/income group, a university graduate and physical science student and peer group influence as a factor for his involvement in terrorism.

According to the then Nigeria's Minister for Information, Dora Akunyili, UFA could not be said to have been influenced within Nigeria because his activities and links with international terrorists could be traced to Yemen and not Nigeria. She was of the view that the twenty-three year old, underwear bomber, schooled in a British School where his touch with African values was marred by his exposure to western culture which further thwarted his African orientation and ethics. This position was in line with Prof. Wole Soyinka, a 1986 Nobel Laureate, opined that the British government should equally share part of the blame with Nigeria. His argument could be linked to a series of attempted bombings of airliners by some British citizens. Perhaps, Soyinka's thought was conditioned by the activities of Richard Reid, a British "Shoe Bomber", who, in December, 2001, attempted to use the same chemical (PETN) for the same purpose as Umar in December 2009. Reid later jailed for twenty years in the UK (Reid's case did not reduce UK to a pariah state) while UFA was sentenced for life imprison for the same offence on 16 February 2012 without option of parole (Babalola, 2012). Nigerian government also argued that terrorist attacks were usually linked to the European states' mosques. The 9/11 attack named Mohammed Atta of al-Quds mosque in Hamburg, Germany; Richard Reid and another 9/11 suspect, Zacarias Moussaouni (a French Moroccan graduate of Business Studies from South Bank University) were linked to the Finbury Park Mosque headed by a cleric, Abu Hamza al-Masri who was later charged with inciting terrorism in Europe (Legrain, 2007:291-2; Burleigh, 2009:442).

UFA was a known introvert, who hardly related with people, perhaps as part of the Islamic training he underwent while in Yemen and from various mosques in London. He would kick against every western idea, even while he paid his family a visit in Kaduna, Nigeria, between November and December 2009. In Nigeria, a general opinion was that his father (a former Chairman of the First Bank, one of the largest commercial banks in Nigeria with its root from London, and once Minister for Economic and Development) is familiar with the British system, therefore could be categorised as one of

\footnotetext{
${ }^{4}$ Rumoured had it that Boko Haram received the blessing of some state governments in the north such as Bauchi, Borno and Yobe with the aim of achieving the vision of Usman Dan-Fodio and late Ahmadu Bello (who formed Jamaatu Nasril Islam), and that of the Sardauna of Sokoto. What remains unclear is that Borno and Yobe states are dominated by non-Hausa/Fulani ethnic groups. The March 2014 kidnap of 278 school girls from a remote part of Borno state brought the issue to a global level, which needs global attention.

${ }^{5}$ A failed state denotes, according to Flint \& Taylor (2007:124), "a state that lacked the infrastructural capacity either to constrain or guide social life or to utilize the potential assets within the state...to maintain social order and economic production." 
the comprador bourgeois, furthering the interest of the West in Nigeria. While studying chemical engineering in the UK, UFA left for Yemen where he was to study the reading and the writing of Arabic language. After a while in Yemen, he left Arabic school hostel and stayed with an Islamic scholar who, being a member of Al-Qaeda, brainwashed and thought him the dexterity at detonating explosives.

\section{Nigeria-US in View}

Worth considering in the two states' relations is the US's establishment of the Africom, which is too expensive for the geostrategic calculation of the Pentagon to abandon. However, the activities of various terrorist's movements in the west and central Africa's littoral states are too serious to ignore. War on piracy, considered as hoste humani generis received international attention as the US, China, Russia and the North Atlantic Treaty Organization (NATO) (Onuoha, 2009:40) spearheaded the programme would not receive proper attention without the success of Africom in which Nigeria has roles to play. Coupled with this is the apparent loss of control of the Eurasia (heartland) ${ }^{6}$ by Washington as a result of the Middle East crises to which America committed a lot of military, financial and human resources with little outcome. This made it necessary to warm towards the GoG imperative as against a mirage result from the region. The establishment of Joint Development Zone (JDZ) between Nigeria and Säo Tome é Principle on the one hand, and Nigeria and Equatorial Guinea on the other hand, with the sharing formula of ration 60-40 would affect any oil alternative supply to the US, if Nigeria is ostracised as a terrorist nation. Not only that, the US oil giants will be affected in term of revenue. The same may lead to political instability, economic crisis and social upheaval in the GoG region as the technological know-how of the two joint projects were supplied by the Nigerian government. The handing over of the Bakassi Peninsula based on the International Court of Justice (ICJ) advice which Nigeria followed to the letter might be revisited by the Nigerian government to attract international attention if the country is politically and economically ostracised.

Also worth looking into is the amount of investment of the US in Nigeria. In the oil and gas sector alone, America cannot afford to lose the state because of high return in its investment (Ate, 2012: 318-9). At the political level, attempt to maintain diplomatic faceoff with the Abuja government would have some spill-over effects on the rest of Africa and beyond, being an undisputable credible hegemon on the continent (McLoughlin \& Bouchat, 2013: 2). Some pro-American anti-Nigerians may be of a view that Direct Foreign Investment (DFI) from the US may dwindle the level of employment in the country. As much as this point is debatable and appears tenable, the investment from the Eastern part of the world, on which China, India and lately, Japan have begun their neo-colonialism in Africa, would not make the exit of America so glaring. Unlike the Chinese and the Indian investments in Nigeria, many of the American investments focus on capital intensive, hi-tech, that attracts a few professionals and in most cases from the middle class extraction. Nigeria could only benefit from labour intensive system in which India and China are currently taking the lead, though with the attendant problems of sub-standard condition of service and the problem of environmental pollution. The French factor may also serve as a balancer and credible vacuum filler through award of juicy oil blocks and other solid mineral exploitation in the country as it was between 1994 and 1998 when Nigeria was internationally ostracised during the Abacha regime (Médard, 2008: 328). America would not like to lose its economic grip on the state as it did in the 1990s

In spite of all the terrorist activities in the Middle East, Saudi Arabia, America continues to maintain good relationship with Saudi Arabia despite the June 2004 Islamic militants beheaded of Paul Johnson, Jr. who was an employee of an American Apache helicopter manufacturing company. The belief of the militants was that the helicopter was used to launch missiles to the Muslims in the region. Instead, the state is noted as a "concentration camp" for the suspected terrorists captured through the US special operations in Albania, Pakistan, Malaysia and Lebanon. This could have been because of the economic import of the state, in the supply of finite fossil fuel to power America economy.

Based on the above analyses, the potentiality of Nigeria to inflict some degree of sanctions on the US could have caused the Nigerian Senate on 5 January 2010 to call for delisting of Nigeria as a terrorist state within seven days (Vanguard 2010. 6 January). The executive arm of government, through the Nigeria's Foreign Affairs Minister, Ojo Maduekwe, summoned the US ambassador to Nigeria, Robin Sanders, and expressed his displeasure on the action taken by the US government as tantamount to hasty generalization. As a conservative government, the Yar Adua's government perceived radical approach of the US political and diplomatic actions as an unfriendly act against Nigeria. This position could have been as a result of the influence of the civil societies such as Non-Governmental Organizations

${ }^{6}$ The classical geo-political thinking of the early part of the 20th century, particularly the views of Sir Halford Mackinder of Great Britain, held that Eurasia was the most important part-the "heartland" of the civilized world, and that whoever controlled this heartland by definition controlled the rest of the world because of the concentration there of population, resources, and industrial might. In classical geopolitical thinking, world politics is essentially a struggle over who will control the Eurasian heartland (cited from Klare, 2003). 
(NGOs), private individuals at the domestic and in the Diaspora, opposition parties (mostly the Action Congress) and political analysts who criticised US position on Nigeria. Otherwise his government would have preferred quiet diplomacy instead.

The Nigerian House of Representatives opined that UFA misadventure blame should be dropped at the doorsteps of the American security outfits such as the Central Intelligence Agency (CIA) and Federal Investigation Bureau (FIB) based on the early warning received from UFA's father. The above reasons made Barrack Obama of America admit that his administration's security arrangement was at fault because of their failure to have averted the attempted Christmas attack. This led to a change in his security personnel and arrangement. Despite the US negligence on the 12/25, Nigeria's foreign policy under Yar'Adua had some lapses, which eventually reduced the state to a toothless bulldog in spite of its important position in the African international relations.

\section{Nigeria's Foreign Policy Lacuna: Implications for UFA Crisis}

Foreign policy of consequences embarked upon by the Yar' Adua/Godluck government is a setback for the Nigerian state as it is only a reactive policy compared with the Obasanjo's (1999-2007) pro-active foreign policy regime. Citizens/consequences foreign policy is an acceptance of irrelevance in the comity of nations where a state relegates the primacy of international relations to economic growth. Crisis of poverty and unemployment are practically abandoned. The globalization of the international economic relations has put the function of economic development in the hand of private sector where issue of enabling environment is being regulated by the various international financial institutions such as the Bank and the Fund. In spite of all that, as mentioned earlier, the politics of prebendalism embarked upon by the ruling political party, People's Democratic Party (PDP) asphyxiated whatever gain that could have accrued to the state through foreign policy position left by Olusegun Obasanjo (1999-2007) administration. The quality of those that dominated foreign policy making is another problem that made the policy less dynamic.

Yar'Adua's kitchen cabinet ${ }^{7}$ that dominated foreign policy only concentrated on signature bonus proceeds from oil blocks allocated to the oil multinational corporations. Foreign Ministry played minimal role during UFA saga. Lack of interest in international relations as against Yar'Adua's predecessor, Olusegun Obasanjo, was a u-turn from dynamic foreign policy. Ojo Maduekwe who was supposed to have more interest in foreign policy is equally a novice in diplomatic maze system. Though he summoned the American Ambassador to Nigeria, Robin Sanders, to his office with an attempt to impress it on the US to delist Nigeria from terror watch-list, his influence was less felt on this. Equating Nigeria with Afghanistan, Algeria, Iraq, Lebanon, Libya, Pakistan, Saudi Arabia and Somalia was considered unacceptable because of an isolated case of attempted terror attack.

The UFA epic brought about a turning point in the relationship between the two states. The belief by the US that arresting and possible jailing and torturing of terrorists would signify finis in the act of terrorism turned out to be a ruse. The concept of martyrdom and anti-America posture seems to have explained the 12/25 saga.

The need to address the root causes of terrorism was captured by an ultra-rightist Republican and once a security advisor before being appointed as the Secretary of State, Condoleezza Rice. She was of the view that "hopelessness (which) provides a fertile ground for ideologies that convince promising youths to aspire not to a university education, a career or family, but to blowing themselves up, taking as many innocent lives with them as possible" are causes of terrorism. As a way forward she was of the opinion that America needed to address the source of the problem (Washington Post. 2003. August 8:7). However, her position was questioned as she could not adequately capture the problem in the Muslim world. Her argument of hopelessness as a singular factor for terrorism other factors are of more of political rather than economic and food security considerations.

The alleged involvement of the Movement for the Emancipation of the Niger Delta (MEND), which was later accused of having some financial support from various international jihadist movements, was, expectedly, denied by the movement. It could be said that some of the environmentalists in the Niger Delta such as Asari Dokubo Mujaiden, Henry Orkah (who is presently serving a jail term in South Africa for his involvement in terror act in Nigeria) among others claimed to be strong members of some terrorist network who sought for financial help from various international jihadist movements.

\footnotetext{
7 The members of the kitchen cabinet are what Tell Magazine (Lagos) described as the Katshina Mafia comprises of the wife of the late President, Turai Yar'Adua, Dr. Yakubu Tanimu, Abba Ruma, Kanti Bello and Dahiru Mangal. For more discussion on this, see Tell, 2008: 24-27 and Adeniyi, 2011: 273. The administration of Goodluck Jonathan is too young to access at this stage, though one can project to the future that because of the incoming elections by 2011, he would like to sacrifice so many foreign policy initiatives for him to get his party's ticket for the election.
} 


\section{Other Likely Sources of Terrorism in Nigeria}

Another area of concentration is the crisis of climate change and its effects on North-Eastern part of Nigeria. The Lake Chad area is another keg of gun powder that could explode anytime soon between sedentary farmers and pastoralists because of arable land for farming and grazing. The colonial legacy of boundary demarcation and delineation, and the continued interest of the West are sources of concern. The Lake Chad is a meeting point of four different states of Nigeria, Niger, Chad and Cameroon. With the receding of the Lake by more than $60 \%$ compared with what obtained in the 1960s, grazing land for the herders and arable land for the grain farmers may lead to emigration of farmers from Chad, Cameroon and Niger towards Nigeria. Possible tension between indigenes and settlers may eventually lead to another crisis through which the terrorists can have their field days in Nigeria as in Mali between the Touaregs and Songhai if not properly managed (Amusan, 2013a \& 2013b).

Not too far from the just discussed avenue for the terrorists to recruit from the vulnerable Nigerians is the question of the skilled irregular migrants from West Africa, Nigeria specifically to the US and the EU states who could not practice their trained skill because of the problem of work and residence permits. These are the type of people who "work in the underground economy characterized by unstable jobs and low pay and pegged to the 3Ds- dirty, demeaning and dangerous jobs" (Adepoju \& van der Wiel 2007:16). These are the group of exploited individuals that cannot engage in labour unionism, but faced harassment from their employers who sometimes intimate immigration department of their existence in their host states. The implication of this are among others, being dehumanized, forced to take the most demeaning jobs irrespective of their education qualification. Frustration-aggression syndrome might force such migrants to engage in whatever will bring food to their tables and be able to remit some to their ancillary interests and an attempt to defray "huge cost of their irregular migration. If such is identified by the terrorists they could promise them all their wants and possibly send money to their family anywhere in the world. The end result? Initiation to terrorism in the name of poverty and a bid to live a meaningful live. The Mumbai terror attack in India is an example of poverty inspired terrorism.

\section{Any Catholicon to the Doldrums as a Matter of Conclusion?}

Several attempts have been made by students of conflict resolution in Nigeria (Imobighe \& Eguavoen, 2006; Obi, 2006; Akanji, 2007; Oyeniyi, 2007; Osita, 2009; Samson, 2009) on the way forward and how to come out of the doldrums the country found herself during and after the UFA saga. The introduction of a true federalism to ensure development at each state's own pace is severally suggested (Young, 1979; Ekeh \& Osaghae, 1989; Oladeji, 2006), but for the need to hold on to power as a means of controlling the state's resources, especially, fossil fuel, has reduced federalism to a unitary system in practice. If federalism, as enshrined in the 1999 Constitution, is religiously adhered to, issues of religious intolerance, allocation of resources and political power sharing would have been catered for.

To nib crises in the bud is another means of checking against terrorist activities in the state. Governor Aliu Muazu Babangida's (Niger State) efforts to root out perceived Islamic fundamentalists away from his state, when some of the members of the anti-western education were deported back to their various countries, is a welcome attempt to check religious crisis. Nigeria should discourage foreign trained imams, mostly from the Middle East, Magreb and Pakistan. These are group of Imams that received financial support from their training school/madrasahs. The essence of this is that political socialization implanted in the Nigerian environment tends to be against the doctrine of secularism as known from 1960. Foreign Islamic training received by UFA could have contributed to his ultra-Islamic fundamentalism in spite of several openings available to him as a product of middle class. With constitutionalism put in place in many of the First World States (FWS) coupled with the global village dictum of international system, the only option, is to have an eagle watch on the proliferation of madrasas (Islamic schools) in Nigeria as many of them are meant to be training ground for potential bombers.

Also of note are those that are not in any way linked to Islamic fundamentalists. The Oklahoma City bombing conspirator (Terry Nichols) and the Unabomber (Ted Kaczynski) that embarked on serial killing and indiscriminate bombing should be looked into. These are the group of people, who, according to Margaret Thatcher (2002: 220-1), "aimed at achieving their goals not just through violence but through the fear of violence. They wish to intimidate just as much as to kill and maim. These groups have no inherent limits; they recognise neither domestic laws, nor international conventions, nor the standards of morality." Their actions may not be too far from socio-economic and political alienation, a la dividend of globalization.

With the global economic recession there has been a movement from ultra lassez farism to a sort of mercantilism which is a confirmation of the poverty of liberalism. Ability to protect a state economic development against foreign domination will do more good for Nigeria as against the Fund and the Bank one-size-fit all system of development. 
Welfarism that ensures even development and provision of employment is ideal for the country in this era of economic disarticulation.

At the global level, as the issue of terrorism knows no border, the US and the European Community should embark on foreign and domestic policies of tolerance where the Muslim communities in their respective states are respected; more so, it should be remembered that many of the suicide bombers are second and third generations' immigrants in Europe and America. As argued by Mohamed Mamdani (2004: 229), "political terrorist is not easily deterred by punishment...and that terrorism has no military solution." Though it is not the intension of this paper to suggest that a special law should be created for the Muslims, their religion should be respected. Where these rights conflict with the state's law, it is expected that the state Constitution should take precedent over any religious belief. Laïcité secularism should be revisited as it conflict with the contemporary highly globalised international system. Secularism introduced after the Thirty-Year war between the Catholic and the Protestant led to the Westphalia Treaty only, which in part, solved the $21^{\text {st }}$ Century religious crises. The European notion of secularism only stopped at division within the Christendom. This would have inspired Walter Bosbach, spokesman for Germany's Christian Democratic Union party, as quoted from (Klausen, 2005:10) to have declared that Germany is a Christian state and should not be forced to accommodate Islam. There is a need to look beyond the Eurocentric secularism of religious tolerance that only accommodates proliferation of different sects in Christianity. Other religious beliefs, Islamic religion, Judaism, Hinduism and others should be accommodated in tune with the globalisation doctrine and the reality of the contemporary immigration that respects no border as captured by the recent theories of immigration at the international system (Legrain, 2007; Koslowski, 2004). With this, the liberal Muslims will be able to expose the fundamentalists. This, as mentioned earlier, is based on an enabling environment for the attainment of human security holistically. With the call for universal human rights by which freedom of religion, freedom of association and freedom of speech are enshrined in many of the civilized states' legal codes, there is a need to promote and ensure respect for other religious beliefs.

Introduction of public diplomacy as adopted by the British Council in some parts of West African states is an attempt to acquit Muslims to the mores and culture of the West is a welcome development provided it is not a means of spying on different Islamic movements. In May 2010, the British Council invited some Imams from West African states to the city of Kano, Nigeria, in an attempt to kow-tow a moderate approach to expose Islamic fundamentalists in the subregion. Introduction of hi-tech to expose the operation of the terrorists is another issue worth addressing. This could be done through readiness of the West to accommodate and learn how to read and write Arabic language. This could be introduced in form of a subject necessary in elementary and high schools because according to Burleigh (2009:469) "some Al Qaeda chatrooms such as The Fortress, The Fields, and Reforms, cannot be accessed without the original Arabic titles." Ability to accommodate other peoples' culture and religion in the age of global migration is long overdue.

\section{References}

Abdalla, M. (2010). Africa's oldest victims of climate change. The African. Com. December 2009/January 2010. Pretoria: ISS.

Adeniyi, O. (2011). Power, politics \& death: A front-row account of Nigeria under the late President Yar'Adua. Lagos: Prestige/Kachifo.

Adepoju, A., \& Van der Wiel, A. (2007). Migration and development: challenges and opportunities for the West African region. Nigerian Journal of International Affairs, 33(2), 9-30.

Agbu, O. (2004). Globalization and international terrorism: the challenges for Nigeria's Foreign Policy. In B. A. Akinterinwa (Ed.), Nigeria's new foreign policy trust (pp. 323-339). Ibadan: Vantage Publishers.

Akanji, O. O. (2007). The politics of combating domestic terrorism in Nigeria. In W. Okumu \& A. Botha (Eds.), Domestic terrorism in Africa: defining, addressing and understanding its impact on human security (pp. 55-64). Pretoria: Institute for Security Studies.

Amusan, L. (2013a). Libya's implosion and its impacts on children. Journal of International Women's Studies, 14(5), 66-79.

Amusan, L. (2013b). Nigeria and its neighbours in the age of climate change: an assessment of the Lake Chad Basin area. In A. A. Akinsanya \& J. A. Ayoade (Eds.), An introduction to political science in Nigeria (pp. 261-282). Lanham, Maryland: University Press of America.

Annan, K. (2005). A global strategy for fighting terrorism. The Guardian. (Lagos). 14 March.

Ate, B. E. (2012). Nigeria-US Relations: a new partnership for Nigeria's economic transformation. In T. A.

Imobighe \& W. O. Alli (Eds.), Perspectives on Nigeria's national interest and external relations (pp. 301-323). Ibadan: University Press.

Babalola, A. (2012). Bomber, Abdulmutalab, gets life sentence in US. The Punch (Lagos, Nigeria) 17 February.

Blair, T. (2007). A Battle for Global Values. Foreign Affairs, 86(1), 79-90.

Blum, W. (2003). Myth and denial in the war against terrorism. Current.org. August 19.

Blum, W. (2006). Rogue State: A guide to the world's only superpower. London: Zed Books Ltd.

Burleigh, M. (2009). Blood \& rage: a cultural history of terrorism. London: Harper Perennial.

Ekeh, P. P. \& Osaghae, E. E (Eds.), (1989). Federal character and federalism in Nigeria. Ibadan: Heinemann Educational Books.

Evans, G. \& Newnham, J. (1998). Dictionary of international relations. London: Penguin Books. 
Flint, C. \& Taylor, P. (2007). Political geography: world-economy, nation-state and locality. Essex: Person-Prentice Hall.

Friedman, T. L. (2006). The world is flat: the globalized world in the twenty-first century. London: Penguin Books.

Imobighe, T. A. \& Eguavoen, A. N. T. (Eds.), (2006). Terrorism and counter-terrorism: an African perspective. Ibadan: Heinemann Educational Books.

Imobighe, T. A. (2006). Rethinking terrorism and counter-terrorism. In T. A. Imobighe, T. A. \& A. N. T. Eguavoen (Eds.), Terrorism and counter-terrorism: an African perspective (pp. 7-28). Ibadan: Heinemann Educational Books.

Imobighe, T. A. (2009). Challenges in categorising domestic terrorism. In W. Okumu \& A. Botha (Eds.), Domestic terrorism in Africa: defining, addressing and understanding its impact on human security (pp. 14-19). Pretoria: Institute for Security Studies.

Jewish conspiracy: the protocol of the learned elders of Zion. (n.d.). Tehran: Islamic Propagation Organization.

Kepel, G. (2004). The war for Muslim minds: Islam and the west. Cambridge, MA: Harvard University Press.

Klare, M. (2003). The new geopolitics. Monthly Review. 55(3), July/August.

Klausen, J. (2005). The Islamic challenges: politics and religion in Western Europe. London: Oxford University Press.

Legrain, P. (2007). Immigrants: your country needs them. London: Abacus.

Maier, K. (2000). This house has fallen: Nigeria in crisis. London: Penguin.

Mamdani, M. (2004). Good Muslim, bad Muslim. Johannesburg: Jacana Media.

Martin, G. (2006). Understanding terrorism: challenges, perspectives and issues. London: SAGE Publications.

MCLoughlin, G. \& Bouchat, C. J. 2013. Nigeria unity: in the balance. Carlisle, PA: Strategic Studies Institute \& U.S. Army War College Press.

Médard, J. (2008). Crisis, change and continuity: Nigeria-France relations. In A. Adebajo \& A. R. Mustapha (Eds.), Gulliver troubles: Nigeria foreign policy after the Cold War (pp. 314-333). Scottsville: University of KwaZulu-Natal Press.

Moïsi, D. (2007). The Clash of Emotions: fear, Humiliation, Hope and the New World Order. Foreign Affairs, 86(1), 8-15.

Moïsi, D. (2009). The geo-politics of emotion: how cultures of fear, humiliation and hope are reshaping the world. London: Bodley Head.

New York Times. (1998). August 22.

Obi, C. I. (2006). Terrorism in West Africa: real, emerging or imagined threats? African Security Review, 15(3), 87-101.

Oladeji, A. (2006). Federalism, resource control and the future of democracy in Nigeria. In E. O. Ojo (Ed.), Challenges of sustainable democracy in Nigeria (pp. 281-299). Ibadan: John Archers.

Onuoha, F. C. (2009). Sea piracy and maritime security in the Horn of Africa: The Somali coast and Gulf of Aden in perspective. African Security Review, 18(3), 31-44.

Oyeniyi, B. A. (2007). A historical overview of domestic terrorism in Nigeria. In W. Okumu \& A. Botha (Eds.), Domestic terrorism in Africa: defining, addressing and understanding its impact on human security (pp. 43-54). Pretoria: Institute for Security Studies.

Richmond, O., \& Franks, J. (2005). Human security and the war on terror. In F. Dodds \& T. Pippard (Eds.), Human and environmental security: an agenda for change (pp. 27-37). London: EarthScan.

Samson, I. T. (2009). Niger delta militancy and the challenge of criminalising terrorism in Nigeria. African Security Review. 18(2), $28-41$.

Tell. (Lagos) (2008). June 16. No.24.

Thatcher, M. (2002). Statecraft: strategies for a changing world. London: Harper Collins Publishers.

Vanguard (Lagos) (2010). 6 January.

Washington Post. (2003). August 8.

Young, C. (1979). The politics of cultural pluralism. Wisconsin: The University of Wisco 